Fecha de recepción: marzo 2015 Fecha de aceptación: junio 2015 Versión final: marzo 2016

\section{Una mirada al borde del precipicio. La fascinación por lo siniestro en el espectáculo de lo real (reality show)}

Vanessa Brasil Campos Rodríguez *

Resumen: Este ensayo recorre el camino de la mirada a través de ciertos conceptos que se encuentran impregnados de tópicos estéticos para detenerse en la caracterización del espectáculo de la contemporaneidad.

Palabras clave: mirada - siniestro - espectáculo - contemporáneo.

[Resúmenes en inglés y portugués en la página 34]

${ }^{(*)}$ Doctora en Ciencias de la Información por la Universidad del País Vasco (España), Profesora titular da UNIFACS - Universidade Salvador - Bahia (Brasil).

Un ojo que quiere verlo todo. Este ojo, parece estar magnetizado por algo que se sitúa más allá de las fronteras de lo visible, de lo permitido, quiere atravesar los umbrales y zambullirse en lo indecible. Nos interesa reflexionar sobre este punto de atracción y sobre lo que magnetiza. Nos sentimos atraídos no solo por la belleza, sino también, y de manera creciente, por la extrañeza. Hay cierta estética que imanta nuestra mirada porque se sitúa en la margen de un precipicio y nos convoca de forma avasalladora: “... en ella lo horrible asume la forma eficaz y fulminante de un abismo que asciende y se desborda, situándose en el campo de visión de una mirada aterrorizada y fascinada”. (Trías, 2006, p. 86)

Vamos a utilizar en este ensayo la noción de precipicio a partir de la idea original de Bataille (1979) que elucida la sensación de vértigo y de fascinación que este abismo nos provoca:

Este abismo se sitúa, por ejemplo, entre ustedes que escuchan y yo que les hablo. (...) Somos, ustedes y yo, seres discontinuos. (...) Ese abismo es profundo; no veo qué medio existiría para suprimirlo. Lo único que podemos hacer es sentir en común el vértigo del abismo. Puede fascinarnos. Ese abismo es, en cierto sentido, la muerte, y la muerte es vertiginosa, es fascinante. (p. 09)

El abismo atrae nuestra mirada como algo terrible y sublime. Bataille (1979) dice que la muerte, por ser abismo, es fascinante. Para penetrar más profundamente en esta cuestión buscamos en Nasio (1994) la noción de fascinación en la que nos apoyamos. 
La fascinación es el modo en el que se actualiza, es el modo en que se manifiesta, la emergencia de una mirada inconsciente. La mirada irrumpe cuando un resplandor fascinante se recorta sobre el fondo imaginario de la visión yoica. (Nasio, 1994, p. 51)

El autor explica que de la misma manera que el inconsciente se manifiesta en las fallas de la lengua, un lapsus, del mismo modo la mirada se instituye en estas fallas en la visión llamada fascinación. Es decir, la verdad que brota del inconsciente surge cuando todo desaparece, todo el mundo imaginario desaparece solo a favor de este foco luminoso, algo que concentra en él toda la luz y suprime a su favor todas las otras imágenes visibles.

Nasio (1994, p. 53), para aclarar todavía más, el tema, cita a Heidegger en El principio de razón: "ver algo y captar propiamente con la mirada aquello que se ve, son dos cosas diferentes". Pues, captar con la mirada quiere decir penetrar con la mirada aquello que de la cosa tiene de más propio, su sustancia. "La fascinación es, en última instancia, la experiencia de estar confrontados a una imagen que evoca de una manera tan pura el goce que despierta en nosotros el goce. Eso es la fascinación" (Nasio, 1994, p. 54). Se trata pues de una experiencia límite.

Es ahí, en el límite, donde nos situaremos para intentar hablar de algo que nos moviliza en este extremo, en el borde de este precipicio. Es nuestra tarea aquí hacer una reflexión sobre este punto que de tan fulgurante puede cegar. Intentaremos pensar las imágenes poderosas que recubren y que ocultan algo que es a la vez maravilloso y terrible como la muerte. En ese sentido, este trabajo pretende analizar un fenómeno significativo de la posmodernidad: el espectáculo de lo real. Dedicaremos en nuestra lectura un enfoque especial a la mirada del espectador y su experiencia de pulsión escópica ${ }^{1}$, una mirada que se sitúa en los umbrales de la fascinación y de lo siniestro.

Lo esperpéntico y lo grotesco han atraído la mirada humana desde la Antigüedad. En la Edad Media poblaron la imaginación humana y se materializaron en las esculturas y en los relieves de las iglesias y catedrales, como nos muestra el escritor Víctor Hugo (2006):

Atrae alrededor de la religión mil supersticiones originales y alrededor de la poesía mil imaginaciones pintorescas. Siembra a manos llenas en el aire, en el agua, en la tierra y en el fuego esas miríadas de seres intermediarios que encontramos vivos en las tradiciones populares de la Edad Media; hace girar en la oscuridad el círculo espantoso del Sábado; pone cuernos a Satanás, pies de macho cabrío y alas de murciélago; es él el que ya arroja en el infierno cristiano las espantosas figuras que evocarán más tarde el genio áspero de Dante y de Milton, o ya le puebla de formas ridículas, en medio de las que servirá de diversión Callot, el Miguel Ángel burlesco. Lo grotesco, si del mundo ideal se pasa al real, desarrolla en él inagotables parodias de la humanidad. (p. 09)

Lo grotesco está presente en las artes plásticas, en el teatro, en la literatura y, más recientemente, en las series de televisión trasmitidas en alta definición. En estas últimas, la máxima definición nos facilita la más perfecta, la más próxima y la más detallada visualización 
del cuerpo humano en toda su singularidad. El vocablo proviene del italiano, la grottesca y grottesco, derivados de grotta (gruta). Estos términos se crearon para designar determinado tipo de ornamentos que se descubrieron a finales del siglo XV en excavaciones realizadas en Roma. En esos espacios subterráneos, reabiertos tras casi mil quinientos años, se hallaron pasillos y salones del antiguo complejo palaciego Domus Aurea, una construcción que había encargado Nerón tras el incendio de la ciudad en el año 64 d.C. De los yacimientos comenzaron a emerger imágenes híbridas, pinturas o esculturas compuestas de personas y divinidades o seres extravagantes, mitad humanas y mitad animales. Es significativo el término grotesco y su historia, pues nos remiten a algo que debería permanecer escondido y que surgió, debería continuar oculto y apareció. El vocablo grotesco está íntimamente ligado al hibridismo.

Fue Víctor Hugo (2006) quien por primera vez colocó el término grotesco al lado de lo bello y lo elevó a la categoría estética en su memorable prefacio a Cromwell.

El cristianismo dirigió la poesía hacia la verdad. Como él, la musa moderna lo verá todo desde un punto de vista más elevado y más vasto; comprenderá que todo en la creación no es humanamente bello, que lo feo existe a su lado, que lo deforme está cerca de lo gracioso, que lo grotesco es el reverso de lo sublime, que el mal se confunde con el bien y la sombra con la luz. (Hugo, 2006, p. 07)

No podríamos dejar de destacar como punto de partida para nuestra reflexión la brillante y original cita de Víctor Hugo, piedra angular para cualquier estudio sobre este tema, pues coloca el surgimiento del confronto entre lo grotesco y lo bello como una de las grandes características de lo que él denomina era moderna. "En el pensamiento de los modernos, por el contrario, lo grotesco desempeña un papel importantísimo. Se mezcla en todo; por una parte crea lo deforme y lo horrible, y por otra lo cómico y lo jocoso". (pp. 08 y 09) Vamos a prestar una atención especial al concepto de siniestro para aproximarnos, aún más, de esta rúbrica estética que pretendemos trabajar en este capítulo. Freud (1999) en Das Unheimliche, (siniestro en español), muestra que la palabra alemana 'unheimlich' es obviamente lo contrario de 'heimlich' ['doméstica'], 'heimisch' ['nativo'], es decir, lo opuesto de lo que es familiar. Y sentencia: "y estamos tentados a concluir que aquello que es 'extraño' es asustador precisamente porque no es conocido y familiar”. (Freud, 1999) Freud (1999) asocia el término "extraño" a personas, cosas y situaciones. Entre ellas aparecen unas imágenes que aluden a amputaciones o lesiones de órganos especialmente valiosos y delicados del cuerpo humano, órganos muy íntimos o personales como los ojos o el miembro viril. Imágenes que aluden a despedazamientos y descuartizamientos. El autor explica que esas imágenes producen un vínculo entre lo siniestro y lo fantástico cuando el ser despedazado es un ser vivo aparente, que parece humano sin serlo. Apunta especialmente hacia una frontera en la que nos acometen "[...] dudas en cuanto al saber si un ser aparentemente animado está realmente vivo; $\mathrm{o}$, al contrario, si un objeto sin vida no puede ser en verdad animado" (Freud, 1999). Es notable cómo a partir del estudio de Freud sobre la estética de lo extraño, de nuevo nos encontramos en el límite, en las márgenes de lo humano/inhumano, de la parte/todo, de lo vivo/muerto. 
Abordaremos, por lo tanto, en este ensayo el término estética a partir del concepto freudiano que propone que "por estética se entiende no simplemente la teoría de la belleza, sino la teoría de las cualidades del sentir" (Freud, 1999). El autor destaca que su interés tiene un foco especial en una rama que generalmente se revela un campo bastante remoto y a la que no se le ha prestado la suficiente atención en la literatura especializada de la estética: el tema de lo siniestro.

No se encuentra nada en absoluto a propósito de este asunto en extensos tratados de estética, que en general prefieren preocuparse con lo que es bello, atractivo y sublime -es decir, con sentimientos de naturaleza positiva- y con las circunstancias y los objetivos que los ponen en discusión, más que con los sentimientos opuestos, de repulsa y aflicción. (Freud, 1999)

Freud aclara que lo siniestro es aquella categoría de lo espantoso que remite a lo que es conocido, de lo viejo y que desde hace mucho es familiar. Es todo lo que debería haber permanecido secreto y oculto, pero que ha emergido. En otras palabras, lo que no debería ser visto y, sin embargo, se muestra, sale de la sombra a la claridad y surge ante nuestros ojos. Freud cita a Jentsch para aclarar qué sería esta sensación de "siniestro" que asalta al espectador:

Al contar una historia, uno de los recursos más exitosos para crear con facilidad efectos de extrañeza y dejar al lector en la incertidumbre de que una determinada figura en la historia es un ser humano o un autómata, es proceder de tal modo que la atención se concentre directamente en esa incertidumbre, de manera que no sea posible penetrar en el asunto y aclararlo inmediatamente. Esto, como hemos afirmado, disiparía rápidamente el peculiar efecto emocional de la cosa. E.T.A. Hoffmann empleó repetidas veces, con éxito, ese artificio psicológico en sus narrativas fantásticas. (Jentsch en Freud, 1999)

Este aspecto mereció un estudio profundo y brillante del filósofo español Eugenio Trías (2006) que valorará la evolución histórica de dos categorías estéticas opuestas, lo bello y lo siniestro, para descubrir lo que ambas tienen de sublime y afirma: "lo siniestro es condición y límite de lo bello".

Es condición (sin su referencia el efecto estético no se produce; sin su referencia la obra de arte carece de vitalidad). Pero es también un límite: la patencia y exhibición de lo siniestro (cruda, sin mediaciones simbólicas) destruye el efecto estético. (Trías, 2006, p. 19)

\section{Los recorridos y las fronteras}

A partir de estas reflexiones iniciales es el momento del análisis. Antes de entrar en la lectura del fenómeno reality show que nos ha movilizado para este capítulo, convocamos 
al lector a iniciar esta aventura de análisis desde dos imágenes poderosas de la historia del arte que se localizan perfectamente en la categoría de lo siniestro.

Vamos a analizar las imágenes según la Teoría del Texto propuesta por González Requena (1996). Se trata de realizar una lectura literal, al pie de la letra. Como afirmamos en Rodríguez, (2011, p. 11) el análisis no es más que un momento de lectura: el momento de la descomposición del texto, del trabajo cuidado, detectivesco, de encontrar en la superficie los elementos que nos conduzcan a su núcleo. Analizar es determinar las elecciones y establecer conexiones entre los elementos del texto, recorriendo su red y descubriendo sus nudos y lazos con otros textos ya conocidos y navegados con anterioridad. Leer es deletrear, seguir el movimiento de la escritura, su ritmo, su cadencia, su textura, sus brillos y sombras, sus aromas, su sabor, es un trabajo en busca del sentido y, para ello, usamos todos los sentidos, ya que realizar un lectura de un texto es sumergirse en él, colocar todos nuestro ser en el proceso. No es una aventura para navegar en superficie; es necesario profundizar, sumergirse y dejarse implicar totalmente hasta encontrar sus entrañas.

Las disciplinas teóricas que guían nuestra investigación son la semiótica, el psicoanálisis y la antropología. Vamos a reconocer los fragmentos que nos envían a otros textos, su relación con la subjetividad humana y, también, procuramos localizar los puntos donde ciertos signos se rompen y emerge lo real en su aspecto siniestro y fascinante. Advertimos que trataremos el texto como un espacio de dialéctica, (González Requena, 1996) de encuentro entre lo que es discurso y lo que se escapa al plano de este discurso. O en palabras de Trías. (2006, p. 18)

Se trata de contemplar siempre el reverso del tapiz, las costuras y los anudamientos que hacen posible la tersura de éste (...). Se trata de situarse siempre en el límite entre ese "resplandor" de vivacidad y de relato y la cara oculta, o sombría, que normalmente se deja fuera de la representación.

Cuando pensamos en este límite entre lo resplandeciente y lo sombrío, la primera imagen que nos convoca es el cuadro de Antonieta Gonsalvus, la Tognina, nacida en Holanda en 1572 y retratada por la pintora Lavinia Fontana.

Se trata de una niña cuyo cuerpo estaba completamente cubierto de pelo, incluso en sus manos. El rostro de Tognina, "la parte visible, permisible y más noble de su cuerpo era al mismo tiempo monstruoso y sin embargo, atractivo para los observadores" (Manguel, 2002, p. 126). Contemplamos a la bella y a la bestia sintetizados en el mismo cuerpo, una niña-lobo, ni totalmente animal, ni completamente humana, sino siniestramente atractiva.

Si el rostro humano era (según la enseñanza de la Iglesia) la capilla del santo edificio constituido por el cuerpo, entonces el rostro de Tognina, infestado de pelo, era como las ruinas sagradas de esa capilla envueltas en la espesura, una muestra de la invasión de la naturaleza envilecida sobre la civilización humana, un sitio donde quienes la contemplaban reconocían la propia ambivalencia de su ser, bestial y humano al mismo tiempo, como si se los revelara en el espejo de una bruja. (Manguel, 2002, p. 117) 
Ella mira al espectador de frente, pero no lo encara totalmente. Parece difícil concentrarse en la humanidad de la niña, pues nuestra mirada está magnetizada por la barba que le recubre toda la superficie del rostro. El vestido de princesa en tonos de gris, bordado en dorado, destaca su condición noble, pero no consigue ocultar completamente lo que el espectador adivina que está por debajo: su cuerpo totalmente peludo. Esta mezcla de animal y de mujer nos conduce a lo más pretérito de nosotros mismos, al tiempo de nuestra primitiva jornada como homo sapiens, aquel instante en el que nos separamos de la animalidad para tornarnos humanos. El retrato de Tognina es un aviso al espectador, es una súplica. Sus manos de niña de doce o trece años sujetan un papel cuyas letras de caligrafía elegante se dirigen al espectador ${ }^{2}$. No importa lo que está escrito. Son palabras materializadas. Es como si la niña por debajo de su máscara de pelo nos avisara: "soy humana, soy portadora de la palabra, de lo simbólico, en suma, no se confundan; mi humanidad viene determinada por la palabra y esta es la única forma de combatir esta aparente animalidad". Tognina, plasmada por los pinceles de Lavinia Fontana, hace resonar su voz hasta la posmodernidad. Y nosotros, espectadores fascinados por su condición mujer/animal o bella/bestia, percibimos que lo que nos atrae, lo que magnetiza nuestra mirada es algo que oscila entre los siniestro y la belleza. Tognina representa este umbral, este límite, esta frontera que cada uno de nosotros intenta ocultar, pero que acaba por aflorar, un punto de mutación entre lo salvaje y lo civilizado.

De la misma manera, Magdalena Ventura, retratada por José de Ribera, produce un incómodo desasosiego, incluso en el espectador contemporáneo al contemplar a una mujer barbuda amamantando a su hijo.

En esta poderosa imagen, el péndulo de lo esperpéntico oscila entre lo masculino y lo femenino, mucho más próxima de un hombre amamantando que de una mujer barbuda con su hijo. Nuestra mirada desliza desde este rostro peludo que nos contempla hacia un lugar nuclear de la representación: la lactancia. ¿No parece que este seno está fuera de lugar, demasiado centralizado? Algo produce un efecto siniestro, de inverosimilitud, como un pecho acoplado, falso. Sin embargo, el bebé está muy cómodo y parece que no repudia en absoluto aquella teta. Siguiendo los recorridos de la mirada deparamos con dos manos demasiado grandes para ser de una mujer. Son manos poderosamente masculinas, como masculina es la cabeza de calvicie prematura para una mujer lactante. Lo que es evidente en este retrato es una total masculinización de la figura retratada que contrasta con su pecho pintado en tonos luminosos. Este se destaca del resto del cuerpo, ilumina al niño y derrama sus tonos amarillentos como una cascada por la ropa de la mujer. Este detalle, como la carta de Tognina, avisa al espectador que lo que está ahí, delante de él, no es un hombre, sino una madre. Esta convergencia entre hombre mujer o, como en el caso de Tognina, entre animal y ser humano recorre la historia en diversas representaciones.

¿Por qué se prende nuestra mirada tan intensamente en estas imágenes siniestras? ¿Por qué las observamos tan insistentemente, escrutando cada detalle, adivinando cada milímetro de un cuerpo disforme? ¿Quién es este otro tan diferente y tan igual a mí? ¿No hay en el espectador algo que oscila entre la humanidad y la animalidad, algo entre Dr. Jekyll and Mr. Hyde? "Todo retrato es, de cierta manera, un autorretrato que refleja al espectador. Como "el ojo no se contenta en ver", introducimos en todo retrato nuestras percepciones y experiencia. En la alquimia del acto creador, todo retrato es un espejo". (Manguel, 2002, p. 175) 
Para mí, estos dos ejemplos extraídos de la pintura son significativos, ya que muestran momentos límite que atraen soberanamente la mirada del espectador. Pero la mirada interesada y atraída por imágenes grotescas no se ve restringida al terreno de las Bellas Artes. Notamos un consumo creciente de imágenes por parte de un espectador cada vez más dispuesto a mirar el ser humano en sus momentos límites, allá donde resulta difícil establecer la definición precisa del objeto retratado: humano/inhumano, masculino/femenino, vivo/ muerto o incluso si se trata de una imagen de ficción o real. El espectador del siglo XXI consume imágenes a través de la televisión o de Internet que muestran de manera explícita escenas de crímenes, autopsias y toda suerte de violencia contra el cuerpo humano. El creciente número de programas creados especialmente para exhibir este tipo de imágenes muestra el poder de atracción de la estética grotesca del espectáculo de lo real.

\section{Lo siniestro y la fascinación en el espectáculo de lo Real}

Basta echar un vistazo a la televisión para depararse con una profusión de las más variadas formas de manifestación de lo siniestro, como cuerpos mutilados o disformes, heridas o cadáveres en primer plano, seres hermafroditas o imágenes de órganos sexuales anómalos. Cuerpos putrefactos y en descomposición se muestran a diario en las series de ficción de televisión, tales como CSI, CSI NY, CSI Miami (Sony TV, AXN), Body of proof, Bones, para citar algunas. Pero también podemos acompañar autopsias o escenas de crímenes reales en los programas Dra. G. médica forense, Os investigadores, Médicos detectives, entre otros. Algunos de estos programas mezclan ficción y realidad; autopsias e intimidades se revelan al mismo tiempo en el que actores dramatizan las escenas de los crímenes, como en el caso de la muerte de P.C. Farias, presentado e investigado en el programa inicial de Linha Direta (Línea Directa). En definitiva, la carne humana se ofrece para ser consumida y devorada por los ojos cada vez más hambrientos de los espectadores.

En el ámbito del discurso televisivo, utilizamos el término inglés reality show, que no ha sido traducido al portugués, tal vez porque ya estuviese cristalizado en la opinión pública antes de penetrar en la televisión brasileña. Pero, si por un lado el nombre no tiene su versión nacional, su fórmula ya se ha adaptado perfectamente a nuestra programación brasileña. Dentro de la categoría "espectáculo de lo real” englobamos todas aquellas manifestaciones mediáticas contemporáneas en las que lo real sustituye a la ficción o se confunde con ella. Lo Real y su "espectacularización" emergen en programas en los que funciones como la informativa y la de entretenimiento se mezclan confundiendo al espectador.

Nos basamos en González Requena ${ }^{3}$ cuando adoptamos la denominación de "espectáculo de lo real" para el término reality show. El autor parte de la noción de real en Lacan (1992a, 1992b, 1993, 1995), para ampliar este concepto al aportar que lo real no es la realidad, pues la realidad es un espacio tejido, construido con discursos, con signos. La realidad sería aquello que pertenece al mundo que manejamos, que entendemos, que pensamos, que está sometido a cierta lógica y que, por eso mismo, nos resulta comprensible.

González Requena (1992, p. 2) define lo real como lo que está siempre excluido del orden de los discursos. Es aquello que se manifiesta frente a estos discursos como algo extremamente resistente. Aquello que, en el límite, es siempre ininteligible; es el absolutamente 
Otro. "Lo real está ahí. Es. Con independencia de toda consciencia que pretenda pensarlo. Se diferencia netamente, por eso, de esa otra cosa que llamamos la realidad: el mundo todo ordenado, pensable, inteligible para esta especie, la nuestra, que se obceca en pensarlo". (González Requena, 1998, p. 8)

$\mathrm{Al}$ género reality show, el espectáculo de lo real, pertenecen los programas o fragmentos de programas que presentan acontecimientos seleccionados en función de su potencial dramático-espectacular, muchas veces bajo el ropaje de prestación de servicios públicos, de interés filantrópico o social. De este género de fronteras cada vez más difusas forman parte los más variados segmentos televisivos, que muchas veces utilizan como recursos la trasmisión en directo, la cámara en la mano y una posproducción y edición limitadas, elementos que buscan ofrecer al espectador una sensación de verosimilitud. Por otro lado, incluimos en el género las recreaciones dramáticas de hechos que no pudieron trasmitirse en vivo: las simulaciones. En el género reality show también se encajan ciertos juegos retrasmitidos por Internet o por la televisión paga durante 24 horas y con ediciones diarias en la televisión abierta, como es el caso de Big Brother.

En el espectáculo de lo real el aspecto radical de la imagen invade la pantalla. La materia de los cuerpos, en sus momentos más extremos, aparece ocupando todo el espacio y, en consecuencia, toda la mirada del espectador que las consume.

El espectáculo de lo real posee una carga tan dramática como lúdica, trivializa la violencia, la intimidad y la muerte, lo que fascina al espectador. Según Imbert (2002), esta fascinación está patente en los géneros informativos por excelencia, los telediarios, pero también es constatable en programas híbridos en los que se produce una dilución o degradación del informativo, del discurso de la actualidad:

En todos los programas basados en sucesos, ya sean éstos sociales, mundanos, triviales o simplemente personales, pudiendo pertenecer tanto a la actualidad rosa como a la negra: véanse las reconstituciones al modo de los reality show, sacadas de sucesos reales, o los docudramas que reconstituyen hechos cruentos o escenifican juicios sobre crímenes célebres o figuras de los grandes asesinos de la Humanidad, como existen en Estados Unidos. (Imbert, 2002, p. 24)

Ni siquiera los programas de variedades han huido de este fenómeno que comenzó a dominar la televisión a partir de los años 90. En Brasil, algunos presentadores como Ratinho, Leão, Gugu Liberato y Faustão, llegaron a conquistar niveles máximos de audiencia cuando mostraron en vivo para el público, del auditorio y de casa, figuras esperpénticas, seres humanos deformados, casos típicos de la literatura médica y personas portadoras de anormalidades de todas las formas. Surgió una especie de nueva pornografía biosanitaria, como ha definido Ferré (2003). La intimidad, la singularidad de cuerpos humanos era expuesta ante las cámaras para el disfrute de millares de miradas ávidas por ver cada vez más. Si por una parte la televisión de la última década del siglo XX e inicios del XXI exageraba en la exhibición de cuerpos e intimidades, el espectador demandaba una mirada más allá para consumir imágenes cada vez más explícitas. Prueba de ello es el hecho de que este tipo de programas eleva significativamente los índices de audiencia. Pero existía un espa- 
cio en el que la cámara aún no había penetrado: el espacio de la intimidad de los hogares. En el segundo milenio irrumpe la fórmula game del reality show, un juego en el que algunos personajes desconocidos o famosos, encerrados en un espacio durante determinado tiempo (sin la posibilidad de salir, a no ser por exclusión o desistimiento) acatan ciertas reglas y son observados por más de 20 cámaras durante las 24 horas del día. Casa dos Artistas, Big Brother, Acorrentados, A Fazenda son apenas algunos ejemplos del género en Brasil.

\section{Bienvenidos al mundo de lo Real}

En Argentina los programas del género reality están entre los campeones de audiencia. La gran mayoría pertenece a la productora holandesa Endemol. Es notable la literalidad de los textos que anuncian los programas en el sitio de Endemol Argentina: "Cámara Testigo es la realidad en directo. Un programa sin intermediarios, donde los hechos de la realidad se muestran tal cual son. Sin periodistas, sin cronistas... Sólo la cámara -la imagen que ella capta- y el espectador. Ni más ni menos"4. Cuando analizamos este texto al pie de la letra notamos que en el programa Cámara Testigo (TV América) el espectador establece una relación directa con la cámara que muestra los hechos, "sin intermediarios, sin periodistas, sin cronistas", es decir, no existe un tercer elemento que desempeñe un papel de mediador entre la cámara y el espectador. En este sentido, el sujeto delante de la cámara se siente como frente a un espejo, ojo con ojo con el espectáculo de lo real y se transforma él mismo en testigo ocular.

Código penal, emitido por TV América, promete, a su vez, presenciar todos los delitos y sucesos. La mirada del espectador se convierte en una cámara de múltiples facetas u ojos; todo puede verse desde todos los ángulos como promete el sitio de Endemol: "Código es un magazine periodístico que muestra el delito desde todos sus ángulos, utilizando un formato similar al del documental." De esta manera, el espectador tiene la ilusión de estar viendo todo como si se tratara de un documental, aunque no lo es, pues en realidad es un formato cuidadosamente maquillado que le otorga el estatus de veracidad a lo que tres periodistas narran.

Policías en Acción (Canal 13) ofrece al espectador una invitación para entrar en el "mundo real". La productora Endemol caracteriza el programa como un reality en formato docudrama: "Mostrando "ambas caras de una misma moneda", protagonistas reales son seguidos por cámaras y equipos de producción las 24 horas. (...) Policías en Acción... Bienvenidos al mundo real". Es significativo el propio texto de la productora y el énfasis en la palabra real para anunciar su producción. Como destacamos anteriormente, en el espectáculo de lo real, es lo real y no la realidad lo que emerge en las entrelíneas del texto, ya sea periodístico o televisivo.

Resaltamos que nos interesa trabajar con esta mirada que se sitúa en la frontera, en el límite entre ficción o documental, imaginario o real, masculino o femenino. En este último caso, es muy ilustrativo el programa intitulado El secreto de Miriam (TV América). En el sitio de Endemol Argentina una interrogación convoca al espectador: “¿Qué tiene Miriam que otras no tienen?" Se trata de un reality en el que seis hombres deben seducir a la modelo mexicana Miriam. "Pero ellos ignoran por completo que ella es verdaderamente "él”. 
El afortunado ganará 17.000 dólares y pasará una semana de pasión en un yate a solas con ella. Ellos no saben que Miriam es un travesti”. Ya que el texto del sitio de Endemol informó al espectador sobre el misterio que contiene el programa, podemos responder a la cuestión que le fue propuesta. Lo que Miriam tiene que las otras no poseen es un pene. Es decir, se trata de una mujer fálica. Una mezcla de hombre/mujer o una mujer "completa", sin fallas, la mujer ideal soñada por todos los niños en sus más pretéritos devaneos infantiles. Para el fetichista, Miriam representa la materialización de todos sus deseos infantiles ${ }^{5}$. Esta imagen de una mujer todopoderosa, perfecta a los ojos masculinos, se explota mucho en la publicidad seductora, pues vemos surgir en los anuncios impresos y en los comerciales de televisión a una mujer total a la que nada le falta y es por ello el objeto de deseo para una mirada masculina inebriada ${ }^{6}$. En el reality, El secreto de Miriam, el "afortunado" tendrá todo al lado de su adorada, pues no poseerá a una mujer, un ser carente, sino a un ser que lo tiene todo porque nada le falta.

Al contrario que Magdalena Ventura, de Ribera (analizada anteriormente), Miriam es una modelo hermosa, agradable a la mirada, que provoca atracción en el espectador y no repulsa. Ahí reside para nosotros un límite tenue, una línea muy fina, ya que el espectador sorprendido, como si fuera el participante del reality, permanece entre la fascinación y el estupor al ver que la imagen de una mujer tan linda es realidad un hombre.

¿Qué más quiere, qué más puede desear, si cuanto deseaba se ha hecho realidad? Eso es lo que vemos ahora: un hombre que ha satisfecho en lo real o su deseo [...] ¿Pero el resultado de ello es siniestro (O no es eso lo siniestro, el cumplimiento en lo real de un sueño que al fin se revela pesadilla? (Trías, 2006, p. 115)

Lo que realmente importa en el género es ofrecer a la mirada del espectador un gozo inmediato que alimente ese instinto primario e incontrolable: la pulsión esópica.

El concepto de pulsión escópica permitió al psicoanálisis restablecer una función de actividad para el ojo, no más como fuente de visión, sino como fuente de libido. Allí donde los antiguos tienen el concepto de rayo visual y de fuego de la mirada, el psicoanálisis descubre la libido de ver y el objeto mirada como manifestación de la vida sexual. Allí donde estaba la visión Freud descubre la pulsión. (Quinet, 2002, p. 10)

La mirada es el sentido rey de nuestra posmodernidad. Todo se hace para él, para su confort, para su deleite, para su gozo. Todo para ampliar la mirada, de telescopios a microscopios y, para embriagar la mirada, de imágenes digitales a $\mathrm{HD}$, de exhibiciones en 3D a universos virtuales. Todo, absolutamente todo, se crea para satisfacer la mirada. Un todo que pretende que nada permanezca excluido del discurso. Todo se puede mostrar, sin barreras o límites, incluyendo la muerte, el sexo y la violencia."(...) todo es espetacularizado, es decir, evocado, provocado, articulado en imágenes, en signos, en modelos consumibles" (Baudrillard, 1995, p. 205). Pero este "todo" se puede mostrar; y que "todo" se pueda mostrar conduce al vacío de sentido, al vacío de identidad, a la nada, un espacio ausente de 
toda estructuración simbólica: un agujero negro que repele todo sentido y todo deseo del espectador. En otras palabras, el consumo constante de este tipo de imágenes puede causar un vacío en el sujeto, un espacio que nunca se colma y, por ello, su demanda continúa creciente, pues el individuo nunca se sacia.

\section{De la fascinación al horror}

La pulsión escópica es siempre primordial y tiende al gozo, el más-de-la-mirada, como lo denomina Quinet (2002). Así, donde existe el imperativo igoza! nombrado por Lacan (1992b), en el campo escópico podemos leer: ;Goza, ojo, goza! Este gozo está dirigido hacia un sujeto impelido a mostrarse, cuyo imperativo había sido: ¡Muestre!, ;exhiba!, ¡desnúdese! Entre el más allá del placer de mirar y el más allá del placer de exhibirse existe un terreno que va de la fascinación al horror. Dice Quinet:

El gozo escópico es el gozo de los espectáculos y también el gozo del horror, pues la mirada no puede verse a no ser al precio de la ceguera o de la desaparición del sujeto, lo que indica que toda pulsión es también pulsión de muerte. (Quinet, 2002, p. 49)

La mirada del espectador de este tipo de espectáculos de lo real desea cada vez más; tanto desea penetrar en lugares no visitados anteriormente como ir más allá de lo visible, pero acaba por situarse en el umbral del sexo y de la muerte. Imágenes pornográficas, sexo explícito y cuerpos disecados o en putrefacción sobre la mesa se ofrecen a los ojos ávidos de los sujetos ante las pantallas ${ }^{7}$ de una televisión cada vez más plana y más plena.

El gozo de la mirada se confirma en el momento en el que se produce, en el aquí y ahora de la observación, un despedazamiento, un desgarro. Algo rompe el envoltorio. La piel y la carne se revelan a nuestra mirada en su extrema singularidad. En otras palabras, el momento auge de los espectáculos es aquel en el que la figura se rompe, aparece una fisura, una herida y surge el interior del cuerpo. En suma, el ápice del espectáculo de lo real es el momento en el que caen todos los velos. Lo real aparece porque consigue derrumbar todos los signos que protegían la interioridad del ser humano. La estrategia del espectáculo de lo real es la de una violación visual, pues se trata de violentar la intimidad del otro a través del órgano ojo. Más que un voyeur, el espectador contemporáneo se transforma en detective $^{8} \mathrm{y}$ tienen a su disposición una infinidad de herramientas y arsenales que le permiten, como en ninguna otra época, consumir y disecar las imágenes, escudriñar la escena del crimen, penetrar en los cuerpos.

El espectador difícilmente se ausentará del recinto en el que se exhibe una imagen violenta o una escena más explícita. Muy al contrario, permanecerá atento, deseando que la imagen se prolongue, que la destrucción se repita y, siempre que sea posible, en cámara lenta. El gozo escópico exige que el objetivo de la mirada se demore y se amplifique.

¿Pero qué es eso que magnetiza nuestra mirada contemporánea? ¿Qué es eso que al mismo tiempo nos fascina y nos hiere, nos atrae, nos hiere y nos provoca cierto gozo obsceno? El 
carácter fascinante de una imagen que moviliza el campo escópico asume las más variadas formas y matices, algunos incluso repugnantes.

\section{Linha Direta (Línea Directa): Análisis del programa sobre el caso P.C. Farias}

En Brasil fue notable la sofisticación del programa Linha Direta (Línea Directa), de la red Globo", cuyas escenas de "simulación" reproducían con tal perfección los detalles de los delitos, al basarse en fotografías de los peritos, testimonios de policías y testigos de los crímenes, que tornaba casi imperceptible para el espectador establecer la frontera entre ficción e información. De hecho, es esto lo que procura este tipo de espectáculo: que imaginario y real se mezclen, se fundan y se confundan, eliminando fronteras de tiempo y espacio, pues lo que importa es el aquí y el ahora del espectáculo para crear una ilusión de presente, en un espacio habitado únicamente por el sujeto que mira y la imagen que se le ofrece para su consumo.

Vamos a analizar a continuación el espectáculo Linha Direta, intitulado Caso de la muerte de P.C. Farias, el primero de la serie que inauguraba uno de los programas más vistos de la televisión en Brasil ${ }^{10}$. El caso investigado en ese espacio televisivo se refiere a P.C. Farias, tesorero de la campaña electoral del expresidente de Brasil Fernando Collor de Mello. P.C. Farias fue hallado muerto en la cama, al lado de su novia, Suzana Marcolino. El resultado de la pericia atestó que Suzana había matado a P.C. y después cometió suicidio. Sin embargo, la opinión pública y la prensa no dieron crédito a esa versión.

Vamos a comenzar nuestro análisis por el escenario, primer contacto visual del espectador con el espectáculo que ofrecía el programa. El espacio escénico de Linha Direta es representativo gracias al cuidado en la disposición de elementos, objetos en escena, iluminación y colores. Algunas paredes estaban erguidas con viejos ladrillos aparentes, mientras que otras estaban revocadas en tonos de tierra con textura tosca. La materia prima utilizada ya conecta al espectador con un universo de submundos y calabozos.

Una luz tenue, casi en penumbra, mal ilumina al presentador, sentado sobre una mesa y cuyo rostro se pierde en sombras. En primer plano, más iluminados que el fondo de la imagen, algunos objetos componen el ambiente: una pantalla de ordenador con un número de teléfono en blanco sobre fondo rojo, una caja de CD y un bloc de notas sobre una mesa. Estos elementos del escenario remiten a un lugar fronterizo entre lo primitivo y lo civilizado, pues los objetos tecnológicos ligados al conocimiento contrastan con la pared que recuerda a la de un calabozo. El espectador puede intuir en la escena el significado de que algo misterioso que permanecía escondido está a punto de revelarse, de emerger del submundo de las pasiones humanas primarias. Nos atrevemos a afirmar que alguna cosa en este ambiente proviene de lo profundo, de lo desconocido, del lado animal que porfía en superar a lo humano. En este sentido, el crimen, el asesinato, la pulsión de muerte, en suma, van a ser explorados en el programa que ofrece esa línea directa con el otro lado del ser que mira.

Comandando el espectáculo observamos a un presentador, Marcelo Rezende, cuyos ojos, inmersos en marcos de profundas ojeras y cejas arqueadas, nos interrogan, o mejor, interrogan ese deseo profundo que hay en nosotros. Su voz, como su mirada, es cavernosa. Pronuncia las palabras de forma pausada. Se mueve por el escenario al ritmo de la ban- 
da sonora del programa, cuyos acordes agudos de violines recuerdan los grandes films de suspense y misterio, como la banda sonora de Bernard Herrmann en Psicosis (1960), de Alfred Hitchcock. Rezende se encaja placenteramente en el escenario en el que es la autoridad absoluta y domina el texto como un ilusionista. Podemos establecer otra conexión con el cine al nombrar a Hannibal Lecter ${ }^{11}$ (Anthony Hopkins) en El silencio de los corderos. El personaje, cuyos ojos también se perdían en la oscuridad, imperaba en un submundo en el que paredes de ladrillo y piedra abrigaban a los más peligrosos serial killers estadounidenses. Lecter, con su voz grave, siniestra e hipnotizadora, consiguió encantar a millones de espectadores en todo el mundo, envolviéndolos en una atmósfera de fascinación y terror. Marcelo Rezende tiene esta misma capacidad de fascinar que encanta y asusta. Así, nos dejamos llevar por este mago del reality show.

Rezende convoca al espectador a participar en una investigación que realizó el equipo de Linha Direta en el que se desmontaba la historia oficial y que apuntaba hacia la tesis de la existencia de una tercera persona en la escena del crimen. Alertamos que no nos interesa en este análisis discutir la veracidad de cada versión, la oficial o la presentada por la Globo. Nuestro objetivo es mostrar las estrategias del espectáculo montado en la emisión del programa Linha Direta, caso P.C. Farias, para fascinar al espectador e atrapar su mirada. Marcelo Rezende presenta el caso y se aproxima poco a poco a una gran pantalla que muestra la foto de la pericia del cuarto de P.C. Farias en la playa de Guaxuma donde fue hallado muerto al lado de su novia, Suzana Marcolino.

Se trata de la fotografía de los peritos, pero el logotipo de la televisión Globo está situado estratégicamente sobre la imagen, en la esquina superior derecha, en color y, en marca de agua, abajo, en la esquina inferior derecha. La fotografía de los cuerpos de la pareja ocupa dos tercios del encuadre, mientras que el presentador, en plano americano, se dirige al es-

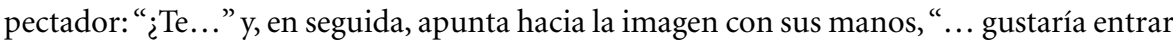
en este cuarto conmigo?"

Vamos a intentar leer al pie de la letra esta llamada de Rezende. En lenguaje conativo nos invita a penetrar en el local del crimen, pues al hablar apunta hacia la foto de la pericia. Este es el llamamiento para el espectador: ir guiado por las manos del presentador al espacio real (ya que recordamos que se trata de la fotografía pericial) en el que los crímenes ocurrieron. ¿Cómo es posible? Para el espectáculo (y, a su vez, su espectador) de lo real no hay límites entre ficción y realidad. Todo es posible, incluso transitar en el tiempo y entrar en espacios cerrados. Nunca la comprensión tiempo/espacio, característica de la posmodernidad ha sido tan bien interpretada y vivida por el espectador contemporáneo. A partir de ahí, de esa invitación, somos transportados a un escenario en el que vemos el desarrollo de los acontecimientos.

La fotografía oficial de la pericia que exhibe los dos cuerpos da paso a un escenario que reproduce perfectamente el local del crimen: los mismos colores en las paredes, lámparas idénticas y sábanas con estampa similar cubren la cama de la pareja.

Sobre este escenario, encuadrado por la cámara en el mismo plano que el de la fotografía de la pericia van surgiendo palabras. Letras se materializan una tras otra al ritmo de una vieja máquina de escribir: "Madrugada de sábado a domingo, 23 de enero de 1996; casa de playa de P.C. Farias; playa de Guaxuma - Maceió/AL". La cámara en lenta panorámica a la izquierda va mostrando a dos personajes de pie, al lado izquierdo de la imagen: un hombre 
y una mujer, inmóviles, mirando al vacío. La semejanza de los actores con Paulo César Farias y Suzana Marcolino es evidente. Ninguna palabra alertando de que la escena es una simulación se añade a la imagen.

¿Esto quiere decir que lo que vemos se trata realmente del local y de la hora del crimen y no de una representación? Por lo menos es así que el telespectador desavisado percibe y lee en la imagen. No en vano ha sido invitado y está en el local exacto del crimen.

Inusitadamente, la pared situada tras la pareja se mueve, se desliza hacia la izquierda acompañada de un ruido metálico grave. El escenario se desmonta como la versión oficial. Surge en escena una tercera figura, la del presentador Rezende, localizado en el espacio entre los dos personajes y constituyendo el vértice superior de un triángulo compositivo. Siempre cuestionando la versión oficial del crimen, Rezende se va aproximando lentamente de la pareja, pero se detiene en la línea divisoria sobre la que se deslizó la pared, que separa la parte exterior del escenario del interior del cuarto. Por fin, cruza la línea, penetra en el dormitorio, pasa entre el hombre y la mujer y cuestiona dirigiéndose al espectador: “¿Qué habrá ocurrido en este cuarto en la playa de Guaxuma, en el litoral de Maceió?" Mientras plantea la pregunta su mirada se desplaza del espectador hacia la cama y a ella apunta con manos de prestidigitador mientras enfatiza la expresión "en este cuarto". Evidentemente el analista o un espectador menos fascinado con el espectáculo saben que "en este cuarto" no ocurrió nada, pues se trata de un escenario montado y desmontado constantemente para la representación. Sin embargo, para el espectador común la frase "lo que ocurrió en este cuarto" se percibe de manera diferente. Ella conecta al sujeto ubicado frente al televisor con la verdad. "Este cuarto" pasa a ser el cuarto de los acontecimientos reales, la escena del crimen.

Marcelo Rezende durante su explicación se ocupa de desarmar la versión oficial del homicidio de P.C. seguido del suicidio de Suzana Marcolino para montar la versión de un doble asesinato y la presencia, por lo tanto, de un tercer elemento en el local del crimen. El presentador encarna, de esta manera, este tercer elemento al situarse en todo momento entre los dos amantes y al "invadir constantemente la escena del crimen". Curiosa estrategia, pues como el espectador también ha sido invitado a entrar con él en el cuarto del crimen, acaba identificándose con este tercer elemento. Solo habría evidentemente una manera de estar allí: fundiéndose en la figura de este tercer personaje (que el programa afirma que fue el asesino) encarnado por Rezende. En varias tomas, la cámara ayuda a componer este artificio al encuadrar los pies de un hombre e ir lentamente recorriendo su cuerpo hasta detenerse en el rostro del presentador. Esta estrategia ocurre casi siempre que hace referencia al tercer elemento en el local del crimen.

Nos gustaría enfatizar que este tercer elemento tiene una función narrativa opuesta a la de un tercer elemento simbólico, aquel representado por el héroe o la figura paterna dentro del marco lacaniano. El tercero, en este caso, ocupa la posición del antihéroe, de la no-ley y es esta figura la que será objeto de identificación por parte del espectador, ya que ha sido encarnada por Rezende.

En una escena posterior, un gran reloj de carillón que marca la una se funde con el rostro del presentador.

La representación de las horas que se suceden se muestra con las agujas del reloj marcando el paso de las ocho a las nueve y después a la una de la madrugada. De esta manera, 
Rezende se torna el señor del tiempo y permite al espectador volver al momento del descubrimiento del crimen. La escena muestra, una vez más, el carácter de omnipotencia y omnipresencia del presentador, que domina y determina el tiempo y el espacio que transforma y manipula a su antojo. Nos gustaría resaltar el hecho de que hasta este momento del programa no había aparecido la palabra "simulación" sobre la imagen. Este recurso de edición refuerza el estatuto de "verdad" de la representación. Lo que tiene importancia es el "aquí y ahora" del espectáculo, creando una ilusión de presente siempre presente en un espacio habitado únicamente por el sujeto que mira y la imagen que se le ofrece.

Se oye un tic tac y, a continuación, la voz de un narrador en off. Solamente ahora la palabra "simulación" surge sobre la imagen, en el momento en el que el personaje de la empleada doméstica está barriendo el comedor. Cuando encuentre una bala, el espectador, que ha visto buena parte del programa sin el aviso de "simulación", ya estará inmerso en el velo de la realidad-verdad del programa y no notará que se trata de una escena simulada o teatralizada.

Sin embargo, el auge, el momento supremo de la total fusión de ficción y Real es cuando el casero Reinaldo fuerza la ventana del dormitorio con unas tijeras de jardinería e irrumpe en la escena del crimen. En este instante la palabra "simulación" aparece grabada sobre la escena montada por la producción del programa con los dos actores sobre la cama en la misma posición en la que se encontró a la pareja P.C. y Suzana.

A continuación, un plano detalle de la fotografía oficial de la pericia muestra el local de la entrada de la bala en el pecho de Suzana y sobre ella la palabra "simulación".

El guardaespaldas salta al interior del dormitorio por la ventana. A continuación, la cámara muestra un detalle de la fotografía de los peritos centrada en parte del rostro de P.C. y su hombro derecho. Un movimiento de cámara encuadra el rostro del muerto. La palabra "simulación" permanece todo el tiempo sobre las fotos de la pericia.

El actor que interpreta al guardaespaldas toca el cuello del actor que hace el papel de P.C. para comprobar si está vivo. Ahora aparece la fotografía de la pericia de Suzana que muestra incluso una flecha blanca que indica el local de perforación de la bala. Sobre la foto permanece aún la palabra "simulación".

Toda la escena está marcada y ritmada por una banda sonora que, con tonos de suspense, secuencia todos los fragmentos reales o simulados. Si sobre las fotografías de la pericia la palabra simulación no desaparece, estas imágenes poseen el mismo valor de irrealidad que las escenas simuladas. De la misma manera las escenas simuladas poseen el mismo estatuto de verdad. La verdad se transforma en ficción (simulación) y la ficción (simulación) en verdad. Y es este plato híbrido, mezclado, que será consumido ávida e ininterrumpidamente por el espectador.

Este voyeur embriagado por el montaje que oscila, como la propia cámara, entre una y otra imagen, entre la fotografía de la pericia y la escenificada por el programa, puede que no perciba las fronteras, los límites entre lo real y lo simulado. Todas las imágenes poseen el crédito de "simulación", todas, incluyendo las de la pericia tienen el logotipo de la Globo. Lo real es simulado y lo simulado real y la garantía de ello es de la mayor emisora de televisión brasileña: la red Globo. Sin embargo, y esto es más sintomático, el espectador desavisado "no quiere percibir los límites". Nos gustaría, llegados a este punto, remitirnos a la citación de Jentsch que hacíamos al inicio de este ensayo de que "uno de los recursos 
más exitosos para crear fácilmente efectos de rareza es dejar al lector en la incertidumbre (...) y hacerlo de tal manera que su atención no se concentre directamente en esa incertidumbre (...)". Aquí, el recurso es dejar al espectador en la incertidumbre de si se trata de una imagen real o ficcional, de tal manera que ni siquiera percibe la incertidumbre.

Existe algo en la mirada del espectador posmoderno que exige imágenes cada vez más reales, más verosímiles, más espectaculares. No desea percibir el punto en el que el film se revela truco. Podríamos afirmar, después de observar el creciente interés por programas del género, que una de las máximas del espectador posmoderno sería: "Engáñame, que me gusta”, o en otras palabras: "Engáñame, que gozo", pues es del gozo proporcionado por el espectáculo de lo real de lo que hablamos aquí. En el espectáculo de lo real lo siniestro asume la forma eficaz y fulminante de un imán visual que atrae al sujeto e imanta su mirada. De esta forma el espectador, seducido por la Medusa electrónica, oscila entre las sensaciones de horror y de fascinación y consume con sus ojos este ser que lo inmoviliza: el precipicio.

Fue justamente en la secuencia de imágenes de los cuerpos de P.C. y Suzana (cuerpos reales o representados) donde localizamos la emergencia de lo siniestro en su forma fascinante. Fue justamente en ese umbral, en la frontera entre la fotografía real de la pericia y la imagen simulada, donde algo emergió para el sujeto frente al televisor. Fue en ese punto de cruce en el que ficción y no ficción adquirieron el mismo estatuto donde lo real capturó la mirada del espectador. El programa cumplió su promesa y el voyeur tuvo la sensación, durante unos segundos, de penetrar con su mirada en la escena del crimen, en Guaxuma, el día 23 de enero de 1996, en la casa de playa de P.C. Farias. ¡Él estuvo allí!

Silenciosa, inmóvil y fascinada es la postura del espectador ante las imágenes terribles, que sin embargo atraen poderosamente su mirada. Se siente petrificado, incapaz de apagar su televisor o interrumpir el contacto visual con él y su espectáculo de lo real. Como si sus ojos estuviesen siendo atraídos por un abismo profundo. Como nos explica Trías (2006, p.86) el ojo petrificado en esta visión es un ojo electrizado, fascinado, poseído por el vértigo. Y alerta que a partir de ese instante, ese ojo lo verá todo, todo le será mostrado a partir de ese abismo, es decir, de esa visión que subió y que se apoderó de su campo visual.

Ese abismo que sube y rebosa, como lo define Trías (2006), constituye la más perfecta metáfora de este lado oculto, siniestro y fascinante del espectáculo de lo real. Tal vez por ello, una de las figuras más poderosas y al mismo tiempo más terribles del cine posmoderno sea la de Hannibal Lecter. Personaje psicópata, caníbal, que transita en el umbral de la seducción y de la muerte. Figura cuya aparición en la pantalla parece susurrarnos que el gozo que experimenta el espectador en contacto con los espectáculos de lo real no es inocente, sino algo cotidiano y gozoso. Y advierte: "Codiciamos lo que vemos todos los días. ¿Sus ojos no buscan las cosas que desean?”

\section{Notas}

1. Freud (1999) definió el término "pulsión escópica" como pulsión de placer de mirar y de exhibirse. Lo escópico es, según sus palabras, la primera experiencia de satisfacción que ordenará la percepción del hombre conforme a las coordenadas del deseo. 
2. El texto del papel avisa al espectador sobre el origen y el destino de la niña retratada:

"De las Islas Canarias fui traída

Para el Soberano Henrique II [?] de Francia

Don Pietro, el salvaje.

De allí se estableció en la corte

Del duque de Parma, como yo, [...]

Antonietta, y ahora estoy

El en hogar de la No Signora Donna

Isabella Pallavicina, marquesa de Soragna [...]."

3. Para la distinción entre Real y realidad véase en Jesús González Requena 1989, 1992, 1995, 1996, 1998. Algunos textos del autor está disponibles en www.tramayfondo.com

4. http://www.endemolargentina.com.ar/locales.asp

5. Freud demuestra que el fetiche es un substituto de un pene determinado y muy particular, que tuvo extrema importancia en los primeros años de la infancia, pero que logo se perdió. El fetiche, en suma, es un sustituto del pene de la mujer (de la madre) en el que el niño otrora creyó y que no desea abandonar.

6. Ver Rodríguez (2012) donde analizamos la cuestión de forma detallada en el capítulo VI. 7. Los canales vía satélite ofrecen un menú variado para estos ojos hambrientos. 'C.S.I.' (Crime Scene Investigation), serie que se exhibe en el canal "AXN", muestra casos en los que, además de mostrar la trayectoria del arma del crimen penetrando en el cuerpo y dilacerando los tejidos, podemos participar visualmente de las autopsias, pues las víctimas se muestran siempre en primer plano o la herida en plano detalle. En el respetable Discovery Chanel los voyeurs también pueden disfrutar con series sobre casos reales en los que autopsias y procedimientos de investigación en la escena del crimen se ofrecen de manera extremamente didáctica.

8. Ver João Frayze-Pereira. (2002).

9. El programa Linha Direta (Línea Directa) se emitía los jueves por la noche desde 1999. El primer presentador fue Marcelo Rezende que fue sustituido por Domingos Meirelles. El día 1 de febrero de 2008, La Red Globo emitió una nota de prensa en la que comunicaba su suspensión "temporal".

10. El programa tenía una media de 26 puntos de audiencia y recibía cerca de 2000 llamadas por semana. El programa dedicado al médium Chico Xavier (junio de 2007) registró una media de 30 puntos en el horario.

11. Personaje que Anthony Hopkins interpreta en el film El silencio de los corderos (1991), de Jonathan Demme.

\section{Referencias bibliográficas}

Bataille, G. (1979). El Erotismo. Barcelona: Tusquets.

Baudrillard, J. (1995). A Sociedade de Consumo. Rio de Janeiro: Elfos.

Ferré, J. F. (2003). "Carne de catástrofe: una estética de lo real” en TBR - The Barcelona Review no 38, Barcelona, septiembre-octubre. Disponible en http://www.barcelonareview. com/38/s_jff.htm. Consultado el 04 de mayo de 2013. 
Frayze-Pereira, J. (2002). "Arte contemporânea e banalização do mal: corpo do artista, silêncio do espectador”, en BARTUCCI (ed.), Psicanálise, Arte e estéticas da Subjetivação. Rio de janeiro: Imago.

Freud, S. (1999). "O Estranho" ("Das Unheimliche”), en Salomão, E. (coord.) Edição Eletrônica das Obras psicológicas Completas de Sigmund Freud. Versão 2.0. Rio de Janeiro: Imago, [1999].v. XVII. CD.ROM. Trabajo original publicado en 1919.

Hugo, V. (2006). Cromwell, en Microsoft Word - Hugo, Victor - Cromwell. Doc. Versión 5.2. Uruguay: Ministerio de Educación (MEC) [2006] Disponible en: http://www.edu.mec. gub.uy/biblioteca_digital/libros/h/Hugo,\%20Victor\%20-\%20Cromwell.pdf. Consultado el 04 de mayo de 2013 - Trabajo original del autor publicado en 1827.

González Requena, J. (1992). El discurso televisivo: espectáculo de la posmodernidad, Madrid: Catedra.

González Requena, J. (1989). El espectáculo informativo o la amenaza delo real. Madrid: Akal. González Requena, J. (1996). "El texto; tres registros y una dimensión” en Trama y Fondo no 1 . Madrid, pp 3-32.

González Requena, J. (1998). “En el principio fue el Verbo. Palabra versus Signo” en Trama $y$ Fondo no 5, Madrid, pp. 7-28.

Imbert, G. (2002). "Azar, conflicto, accidente, catástrofe: figuras arcaicas en el discurso posmoderno (entre lo eufórico y lo disfórico)" en Trama y Fondo no 12, Madrid, pp. 19-30.

Lacan, J. (1993). Escritos, Madrid: Siglo Veintiuno.

Lacan, J. (1995). O Seminário. Livro 2, O eu na teoria de Freud e na técnica da psicanálise, Rio de Janeiro: Jorge Zahar.

Lacan, J. (1992a). O Seminário. Livro 3, As psicoses. Rio de Janeiro: Jorge Zahar.

Lacan, J. (1992b). O Seminário. Livro 17, O avesso da psicanálise. Rio de Janeiro: Jorge Zahar. Manguel, A. (2002). Leyendo Imágenes: una historia privada del arte, Bogotá: Editorial Norma. Nasio, J. D. (1994). La mirada en Psicoanálisis. Barcelona: Gedisa.

Quinet, A. (2002). Um olhar a mais. Rio de Janeiro: Jorge Zahar.

Rodriguez, V. B. C. (2011). Além do espelho. Análise de imagens de arte, cinema e publicidade. São Paulo: Casarão do Verbo.

Trías, E. (2006). Lo bello y lo siniestro, Barcelona: DeBolsillo.

Summary: This paper follows the path of looking through certain concepts that are impregnated by aesthetic nuances to stop at the show characterization of contemporaneity.

Key words: look - sinister - show - contemporary.

Resumo: Este ensaio percorre o caminho da mirada através de conceitos que estão impregnados de tópicos estéticos para deter-se na caracterização do espetáculo da contemporaneidade.

Palavras chave: mirada - sinistro - espetáculo - contemporâneo. 